\title{
INTRACELLULAR FLUID LOSS IN HEMORRHAGE
}

\author{
By JOHN D. STEWART ${ }^{1}$ AND G. MARGARET ROURKE \\ (From the Surgical Laboratories of the Harvard Medical School at the Massachusetts General \\ Hospital, Boston)
}

(Received for publication July 3, 1936)

Following a sublethal loss of blood an immediate inflow of fluid into the capillary bed takes place. This fact has been repeatedly demonstrated by measurements of reduction in the concentration of plasma protein, fall in specific gravity of the plasma (1), and diminution in dry residue of serum (2). There seems to be no clear evidence regarding the sources of the fluid by which plasma volume is restored after hemorrhage, the usual statement merely implicating "the tissues." On the other hand, the importance of the splenic reservoir as a source of formed elements after loss of blood is well known.

Attempts to obtain information on this subject by tissue analyses following hemorrhage have on the whole been inconclusive (3), owing to technical difficulties, variation in composition of different tissues, and the small changes to be expected when the volume of blood lost is considered in relation to the body mass.

In one of the first careful studies of base metabolism Gamble introduced the principle, now widely accepted, of the parallel movement of base and water in the body (4). Since potassium is the chief base in cell fluid and since the concentration of potassium outside cells is kept rigorously low, by measuring the amount of potassium excreted from the body above the intake and above that liberated by protoplasmic breakdown a measurement of the extent of fluid lost from cells by diffusion is obtained. By using this principle Butler, McKhann and Gamble were able to compute the loss of intracellular fluid in diarrheal disease of infants (5).

The present study was directed at determining whether the fluid which supports plasma volume under the exigencies of hemorrhage is entirely of extracellular origin; or whether intracellular fluid as well is drawn into the circulating blood.

1 Dalton Scholar, Massachusetts General Hospital, 1935-1936).
PLAN OF EXPERIMENT

Large healthy female dogs of docile disposition were fasted in metabolism cages. The animals were allowed to drink distilled water as desired. Daily determinations were made of weight, rectal temperature and water drunk. Daily catheterization was performed, and usually the animals did not void between catheterizations. After a basal fasting level of excretion of electrolyte in urine was established, which usually required four or five days, the dogs were bled from jugular vein or femoral artery to the extent of 2 to 3.5 per cent of body weight in a single hemorrhage lasting five to twenty minutes. No anesthesia was used except local injection of a small amount of novocaine in case blood was taken from the femoral artery. When the femoral artery was used a point was selected sufficiently peripheral to exclude the factor of anoxemia in the extremity, for, as Baetjer has shown, severe anoxemia leads to diffusion of potassium from the tissues of an extremity into the plasma (6). Following the hemorrhage the animal was not allowed to drink for at least three hours, after which water was given freely. The observations were continued for three to four days after the hemorrhage. Blood samples were taken at appropriate intervals.

An important feature of the experimental plan consisted in conducting the study on the basis of fasting metabolism. In this way the difficulties and inaccuracies of measurement of the electrolyte intake in the food and excretion in the feces were avoided.

Standard analytical procedures were used. Sodium of serum and urine was determined by the gravimetric technique of Butler and Tuthill (13) ; potassium of serum and urine by Fiske's modified cobaltnitrite method in which potassium is reprecipitated as potassium acid tartrate (14); chloride by Wilson and Ball's method of wet ashing with nitric acid and potassium permanganate and Volhard titration (15); carbon dioxide content of the serum according to Van Slyke and Sendroy (16); total nitrogen by macro-Kjeldahl (17); nonprotein nitrogen of serum by micro-digestion and nesslerization (18). Hematocrit readings were made by heparinization of a sample of blood, followed by centrifuging in hematocrit tubes at 2000 r.p.m. until no further change in volume was perceptible, precautions being taken against loss of $\mathrm{CO}_{2}$.

\section{PRESENTATION OF DATA}

In Figure 1 are shown the daily excretion of sodium, potassium, chloride, and total nitrogen and daily urine volume and water drunk, before and 


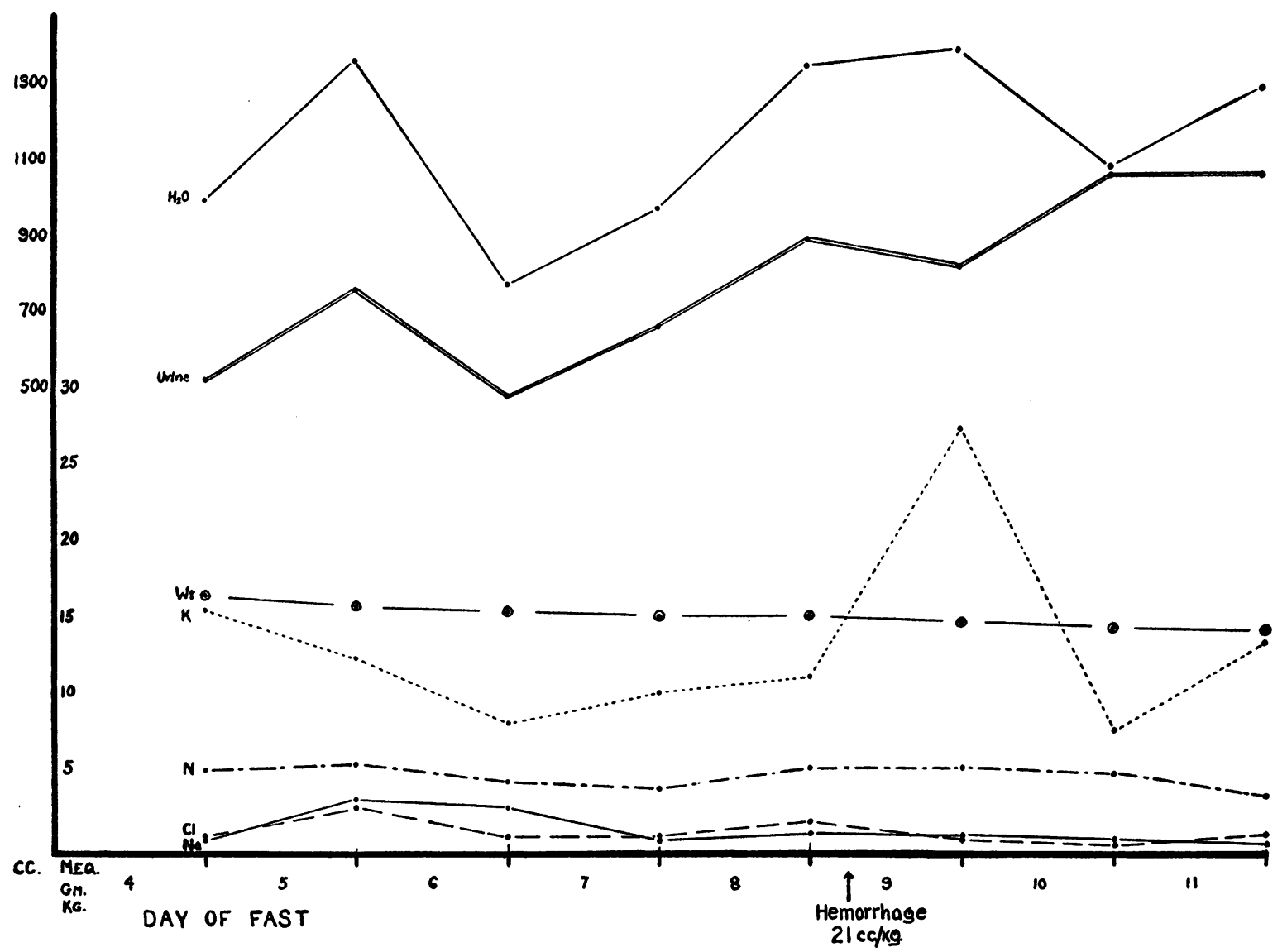

Fig. 1. Excretion Data, Experiment 36-23.

after hemorrhage. It is to be noted that by the fifth day of fasting a basal level of excretion has been reached, although a gradual decrease in the quantity of electrolyte and nitrogen excreted daily is evident. The marked increase in excretion of the intracellular base, potassium, and the lack of change in excretion of sodium and chloride following hemorrhage are clearly shown. The increase in urinary potassium occurs only within the twenty-four hour interval after hemorrhage. No appreciable change in the elimination of nitrogen takes place.

In Table I are shown the quantities of potassium and nitrogen excreted in the urine before and after hemorrhage. The daily basal level of excretion is to be compared with the amount excreted in the twenty-four hours following hemorrhage. The much greater increase in potassium

TABLE I

Data on potassium and nitrogen excretion

\begin{tabular}{|c|c|c|c|c|c|c|c|c|}
\hline \multirow{2}{*}{$\begin{array}{c}\text { Experi- } \\
\text { ment } \\
\text { number }\end{array}$} & \multirow{2}{*}{ Weight } & \multirow{2}{*}{ Hemorrhage } & \multicolumn{2}{|c|}{$\mathrm{K}$ excretion } & \multicolumn{2}{|c|}{ N excretion } & \multicolumn{2}{|c|}{$\mathrm{K}: \mathbf{N}$ ratio } \\
\hline & & & Basal & Posthemorrhage & Basal & Posthemorrhage & Basal & Posthemorrhage \\
\hline $\begin{array}{l}36-12 \\
36-13 \\
36-17 \\
36-23 \\
36-25\end{array}$ & $\begin{array}{l}\text { kgm. } \\
20.15 \\
18.70 \\
12.30 \\
15.40 \\
15.00\end{array}$ & $\begin{array}{c}\text { cc. per kgm. } \\
22 \\
26 \\
36 \\
21 \\
31\end{array}$ & $\begin{array}{c}\text { m.eq. per day } \\
12.5 \\
11.5 \\
12.5 \\
11.1 \\
10.4\end{array}$ & $\begin{array}{c}\text { m.eq. per day } \\
31.0 \\
22.5 \\
24.8 \\
28.1 \\
26.4\end{array}$ & $\begin{array}{c}\text { grams per day } \\
4.1 \\
5.2 \\
3.1 \\
5.4 \\
3.4\end{array}$ & $\begin{array}{c}\text { grams per day } \\
5.8 \\
5.2 \\
4.6 \\
5.4 \\
4.6\end{array}$ & $\begin{array}{l}3.0 \\
2.2 \\
4.0 \\
2.1 \\
3.1\end{array}$ & $\begin{array}{l}5.3 \\
4.3 \\
5.4 \\
5.2 \\
5.7\end{array}$ \\
\hline
\end{tabular}


TABLE II

Experiment 36-25. Excretion data and blood values before hemorrhage, after hemorrhage but before ingestion of water, and after ingestion of water

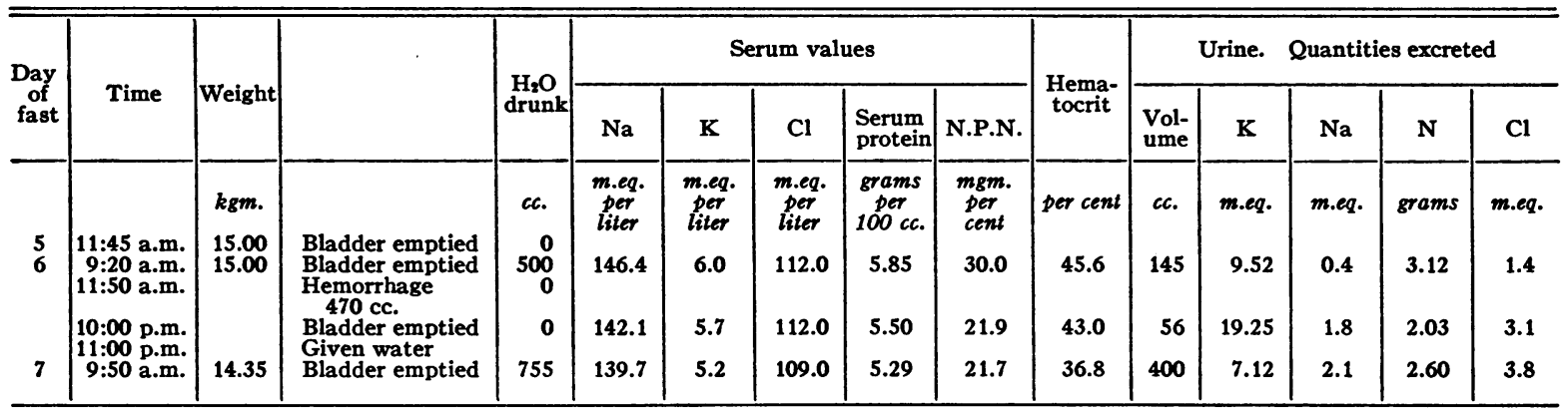

as compared with nitrogen and consequent rise in potassium: nitrogen ratio is clearly shown.

From Table II, it will be seen that during the twenty-two hour period before hemorrhage the dog drank 500 cc. water, excreted 145 cc. urine and $9.52 \mathrm{~m} . e q$. of potassium. In the twelve hours (roughly) after hemorrhage no water was taken, $56 \mathrm{cc}$. urine were excreted containing $19.25 \mathrm{~m}$.eq. of potassium, representing over a fourfold increase in rate of excretion of potassium. The animal was then allowed to drink and took $755 \mathrm{cc}$. water during the following twelve hours. In this period potassium excretion fell off sharply. This experiment was undertaken to show that following hemorrhage the loss of potassium from cells takes place immediately after the loss of blood and not chiefly during the subsequent period when water is drunk. Note the reduction in serum sodium, potassium, nonprotein nitrogen and protein before water is taken, with chloride concentration remaining unchanged.

The data presented in Table III were obtained

TABLE III

Serum concentrations before and after hemorrhage

\begin{tabular}{|c|c|c|c|c|c|c|c|}
\hline $\begin{array}{c}\text { Experiment } \\
\text { number }\end{array}$ & $\begin{array}{c}\text { Hemor- } \\
\text { rhage }\end{array}$ & $\mathrm{Na}$ & $\mathbf{K}$ & $\mathrm{Cl}$ & $\mathrm{CO}_{2}$ & N.P.N. & $\begin{array}{c}\text { Serum } \\
\text { protein }\end{array}$ \\
\hline $36-12$ & $\begin{array}{c}\text { cc. per } \\
\text { kgm. } \\
22\end{array}$ & $\begin{array}{c}\text { m.eq. } \\
\text { per liter } \\
144.5 \\
143.0\end{array}$ & $\begin{array}{c}\text { m.eq. } \\
\text { per liter } \\
4.5 \\
4.2\end{array}$ & $\begin{array}{c}\text { m.eq. } \\
\text { per liter } \\
105.0 \\
107.0\end{array}$ & $\begin{array}{c}\text { solumes } \\
\text { per cent } \\
56.7 \\
55.1\end{array}$ & $\begin{array}{c}\underset{\text { per cent }}{\text { mom. }} \\
22.7 \\
23.1\end{array}$ & $\begin{array}{c}\text { grams } \\
\text { per cent } \\
5.9 \\
5.2\end{array}$ \\
\hline $36-13$ & 26 & $\begin{array}{l}146.0 \\
139.0\end{array}$ & $\begin{array}{l}4.7 \\
4.6\end{array}$ & $\begin{array}{l}107.0 \\
103.0\end{array}$ & $\begin{array}{l}54.6 \\
49.8\end{array}$ & $\begin{array}{l}23.1 \\
28.6\end{array}$ & $\begin{array}{l}6.6 \\
6.1\end{array}$ \\
\hline $36-17$ & 36 & $\begin{array}{l}144.6 \\
143.5\end{array}$ & $\begin{array}{l}5.0 \\
4.6\end{array}$ & $\begin{array}{l}112.5 \\
107.5\end{array}$ & $\begin{array}{l}50.5 \\
52.7\end{array}$ & $\begin{array}{l}23.5 \\
25.2\end{array}$ & $\begin{array}{l}5.7 \\
4.6\end{array}$ \\
\hline 36-23 & 21 & $\begin{array}{l}146.8 \\
136.9\end{array}$ & $\begin{array}{l}5.3 \\
5.0\end{array}$ & $\begin{array}{l}106.0 \\
103.5\end{array}$ & & $\begin{array}{l}28.7 \\
30.8\end{array}$ & $\begin{array}{l}6.7 \\
6.0\end{array}$ \\
\hline $36-25$ & 31 & $\begin{array}{l}146.4 \\
139.7\end{array}$ & $\begin{array}{l}6.0 \\
5.2\end{array}$ & $\begin{array}{l}112.0 \\
109.0\end{array}$ & & $\begin{array}{l}30.0 \\
21.7\end{array}$ & $\begin{array}{l}5.8 \\
5.3\end{array}$ \\
\hline
\end{tabular}

in blood samples taken just before hemorrhage and again twenty-four hours later, the animal having been allowed to drink water freely following an interval of at least three hours after hemorrhage. Serum sodium concentration is invariably reduced, while serum chloride in one instance is increased. $\mathrm{CO}_{2}$ and nonprotein nitrogen show no significant change, while serum protein is invariably reduced. The concentration of serum potassium likewise always falls.

\section{DISCUSSION}

From the data presented it is quite clear that following hemorrhage of the extent produced in these experiments there is a marked increase in excretion of potassium in the urine. Concerning this loss of potassium from the cells two explanations come to mind, either an increase in breakdown of cell protoplasm after hemorrhage, or a simple diffusion of fluid from the cell with reduction in cell volume. Were the potassium liberated from the cells by a process of disorganization of cell protoplasm then there should be an equivalent liberation of nitrogen. By examination of Table I one sees that such is not the case, since the potassium excreted after hemorrhage doubled or trebled, while the urinary nitrogen showed slight or no increase. Hence there is a sharp rise in the potassium to nitrogen ratios. These facts have a clear significance since the maintenance of normal or even reduced concentrations of serum potassium and nonprotein nitrogen following hemorrhage (Table III), excludes an abnormal retention of these elements.

The possibility of a relationship between the water ingested by the animal and the observed 
dilution of the blood plasma and loss of intracellular electrolyte must be considered. It might, for instance, be suggested that a reduction of the total osmotic value of extracellular fluid by retention of ingested water would make necessary a removal of intracellular electrolyte in order to produce osmotic equivalence without a change in the volume of intracellular water. In the presence of such an adjustment, loss of potassium would not be accompanied by a removal of cell water.

To investigate this question the time relationships in the excretion of potassium following hemorrhage were studied. From the data obtained in Experiment $36-25$ and tabulated in Table II it is clear that cell potassium was lost largely during the period of adjustment immediately following hemorrhage and before water was ingested. In this experiment the rate of elimination of potassium in the urine in the twelve hour period after hemorrhage during which no water was taken was over four times as great as during the twelve hour period before hemorrhage. Therefore, the posthemorrhagic loss of potassium from cells is not the effect of osmotic adjustments occasioned by retention of ingested water.

The mechanism of dilution of plasma following hemorrhage can dependably be viewed in the light of Starling's theory $(11,12)$, of counterpoised hydrostatic pressure and colloid osmotic force of plasma proteins in the capillary bed, for the fundamental validity of this theory has remained unchallenged. With reduction of capillary hydrostatic pressure consequent on hemorrhage and favored by activation of the sympathicoadrenal apparatus (7), the unopposed colloid osmotic pressure of the plasma proteins becomes effective in creating a flow of fluid into the capillary bed. From the evidence obtained in these experiments it is clear that movement of fluid out of the cells as well as interstitial areas takes place.

Let us consider this fact further. We are accustomed to regard interstitial fluid as an extensive reservoir from which plasma losses can be readily replaced, its electrolyte composition being so nearly identical with that of the plasma. That water and the unsuitable electrolyte, potassium, should also be immediately withdrawn from tissue cells would not, on teleological grounds, be expected. We must remember, however, that the expectation that plasma losses will be replaced exclusively by interstitial fluid rests on the assumption that there is everywhere in the tissues an appreciable quantity of interstitial fluid between the capillaries and tissue cells. It will be admitted that this premise has not been established to the extent of excluding the possibility that capillary wall may often lie in contiguity with cell wall.

On this basis we venture an explanation of the entrance of cell fluid into the capillaries. One visualizes two sets of colloid osmotic forces in the tissues, one centered within the capillary and created by plasma protein, the other centered within the cell and incident to the high intracellular content of protein. Between the colloid impermeable membranes of capillary and cell generally lies the protein-poor interstitial menstruum. So long as interstitial fluid separates cell membrane from capillary membrane the increased effectiveness of colloid osmotic pressure in the capillary following the hypotension of hemorrhage should be exerted only against the interstitial fluid, and the intracellular system should not be disturbed. However, wherever capillary wall lies in contiguity with cell wall, cell fluid also will come under the influence of the increased effective oncotic pressure in the capillaries, and loss of cell fluid into the capillary take place. Presumably a depletion of the interstitial reservoir would favor this mechanism of reduction in cell fluid volume.

The operation of still another factor must be considered in relation to flow of fluid from the tissues into the capillary bed after hemorrhage, and this is the force termed tissue tension, or tissue turgor. Such tissue tension is little understood and lends itself poorly to analysis. Presumably tissue tension is produced by such factors as the distending force of the intracapillary hydrostatic pressure exerted against the interstitial menstruum and cells, muscle tonus, and gravity. On the reduction in capillary filtration pressure, tissue tension conceivably should favor movement of fluid from the interstitial areas and cells toward the capillary bed. In the present state of our knowledge of the forces involved this can only be conjecture.

Possibly concerned also in the redistribution of 
body fluids after hemorrhage is an alteration in the permeability of the capillary endothelium and cell wall incident to anoxemia and a reduced rate of removal of tissue catabolites. Such a disturbance in membrane function might relate itself not only to the relative impermeability for colloid but also to the selective impermeability of cell wall for specific ions.

Let us consider now the data shown in Table II and compare the concentration of electrolyte in the blood serum before hemorrhage and again twelve hours afterwards, but before water has been taken. The serum sodium falls distinctly, potassium falls, and chloride remains unchanged. Interstitial fluid contains a lower concentration of sodium than plasma $(8,9,10)$, while intracellular fluid probably contains no sodium. Therefore, the inflow into the plasma of interstitial and intracellular fluid will necessarily reduce plasma sodium. On the other hand, interstitial fluid contains a higher concentration of chloride than does plasma while intracellular fluid contains no chloride. The effect on plasma chloride concentration, then, will depend upon the relative amounts of fluid brought into the circulation from the interstitial areas and from the cells, assuming alert renal function. One sees in Table III, that the concentration of serum sodium twenty-four hours after hemorrhage (water having been drunk) was invariably reduced, whereas the concentration of serum chloride was at times increased, at times decreased. In Table II serum potassium twelve hours after hemorrhage (no water drunk) is slightly reduced, in spite of the large amount of potassium carried from intracellular fluid into the urine. The urine excreted during this period had a potassium concentration of 344 m.eq. per liter, or about three times that of cell water. From this it is apparent that cell water was retained in the plasma while the cell electrolytes, unsuitable for plasma construction, were excreted.

In Figure 1 the data obtained in Experiment 36-23 and illustrative of the findings in the other experiments are shown. The power of the kidney to maintain conservation of the needful electrolytes sodium and chloride even after hemorrhage and a posthemorrhagic diuresis is well demonstrated.
A striking and invariable event in these experiments is illustrated in Figure 1. Without exception a diuresis to the extent of 20 to $500 \mathrm{per}$ cent of the average urine volume before hemorrhage occurred during the second day after hemorrhage. This polyuria does not appear to be directly related to water intake. Its mechanism is obscure and will be the subject of further investigation.

\section{SUM MARY}

1. Measurements were made of the daily urinary excretion of sodium, potassium, chloride, and nitrogen by fasting dogs before and after hemorrhage to the extent of 2 to 3.5 per cent body weight.

2. Daily water intake and urine volume were measured.

3. Serum concentration values of the appropriate electrolytes and nitrogen were determined before and after hemorrhage.

4. A sharp increase in urinary potassium immediately after hemorrhage was noted, whereas sodium, chloride and total nitrogen in urine showed no significant change.

5. Regardless of whether water was drunk, hemorrhage was followed by a fall in serum sodium, potassium and protein, while chloride, $\mathrm{CO}_{2}$ and nonprotein nitrogen were variable.

6. A posthemorrhagic diuresis occurred invariably on the second day after hemorrhage.

\section{CONCLUSIONS}

During the process of compensating for blood loss fluid is drawn into the circulation from tissue cells as well as from interstitial areas. The potassium diffusing out of the cells in this process is promptly excreted in the urine.

The authors wish to acknowledge a debt of gratitude to Dr. James L. Gamble for stimulating their interest in the subject of body fluid metabolism and for helpful criticism in the preparation of this paper.

\section{BIBLIOGRAPHY}

1. Moore, N. S., and Stewart, H. J., The variations of the specific gravity of the plasma of the blood and the means available for altering it. J. Clin. Invest., 1930, 9, 423. 
2. Kerr, S. E., Studies on the inorganic composition of blood. I. The effect of hemorrhage on-the inorganic composition of serum and corpuscles. J. Biol. Chem., 1926, 67, 689.

3. Adolph, E. F., Gerbasi, M. J., and Lepore, M. J., The rate of entrance of fluid into the blood in hemorrhage. Am. J. Physiol., 1933, 104, 502.

4. Gamble, J. L., Ross, G. S., and Tisdall, F. F., The metabolism of fixed base during fasting. J. Biol. Chem., 1923, 57, 633.

5. Butler, A. M., McKhann, C. F., and Gamble, J. L., Intracellular fluid loss in diarrheal disease. $\mathrm{J}$. Pediat., 1933, 3, 84.

6. Baetjer, A. M., The diffusion of potassium from resting skeletal muscles following a reduction in the blood supply. Am. J. Physiol., 1935, 112, 139.

7. Schlossberg, T., and Sawyer, M. E. M., Studies of homeostasis in normal, sympathectomized, and ergotaminized animals. IV. The effect of hemorrhage. Am. J. Physiol., 1933, 104, 195.

8. Loeb, R. F., Atchley, D. W., and Palmer, W. W., On the equilibrium condition between blood serum and serous cavity fluids. J. Gen. Physiol., 1922, 4, 591.

9. Hastings, A. B., Salvesen, H. A., Sendroy, J., Jr., and Van Slyke, D. D., Studies of gas and electrolyte equilibria in the blood. IX. The distribution of electrolytes between transudates and serum. J. Gen. Physiol., 1927, 8, 701.
10. Gilligan, D. R., Volk, M. C., and Blumgart, H. L., Observations on the chemical and physical relation between blood serum and body fluids. I. The nature of edema fluids and evidence regarding the mechanism of edema formation. J. Clin. Invest., 1934, 13, 365.

11. Starling, E. H., The influence of mechanical factors on lymph production. J. Physiol., 1894, 16, 224.

12. Starling, E. H., On the absorption of fluids from the connective tissue spaces. J. Physiol., 1895-96, 19, 312.

13. Butler, A. M., and Tuthill, Elizabeth, An application of the uranyl zinc acetate method for determination of sodium in biological material. J. Biol. Chem., 1931, 93, 171.

14. Unpublished method.

15. Wilson, D. W., and Ball, E. G., A study of the estimation of chloride in blood and serum. J. Biol. Chem., 1928, 79, 221.

16. Van Slyke, D. D., and Sendroy, J., Jr., Carbon dioxide factors for the manometric blood gas apparatus. J. Biol. Chem., 1927, 73, 127.

17. Wong, S. Y., The use of persulphate in the estimation of nitrogen by the Arnold-Gunning modification of Kjeldahl's method. J. Biol. Chem., 1923, $55,427$.

18. Folin, O., and Wu, H., A system of blood analysis. J. Biol. Chem., 1919, 38, 81. 